\title{
7. 脳卒中後遺症患者のサーモグラム
}

第 3 報 局所温浴後の皮膚温の経時的変動

弘前大学医学部大池内科

柳一雄玉田友一我那霸安彦工藤良三

竹川弘美山田幸夫 大池弥三郎

黎明郷リハビリテーション病院

弘前大学保健管理センター 小野寺庚午 菅原 英 保 松井哲 郎

\section{緒 言}

脳卒中後遺症患者に対しては, 温水を利用し て水中機能訓練を行なうが，訓練終了後間もな く麻痺側の冷感を訴える患者もみられる. そこ でわれわれは，脳卒中後遺症患者の両下腿の温 浴を行なった後, 皮膚温の経時的変動をサーモ グラムで観察してみた.

\section{対 象}

黎明郷リハビリテーション病院入院中の脳卒 中片麻瘦患者のうち, 脳血栓10名, 脳塞栓 3 名, 脳出血14名, 脳動脈瘤術後左片麻瘦 1 名の計 29 名を観察対象とした.サーモグラフィの時点は 脳卒中発作後 1 か月〜 3 年 6 か月であった.

\section{方 法}

患者の両下腿を $20^{\circ} \mathrm{C}$ 前後の室内に約20分間
露出した後に，まずサーモグラフィを行ない， つぎに，その後ただちに両下腿に 5 分間の温浴 $\left(40^{\circ} \mathrm{C} \sim 45^{\circ} \mathrm{C}\right)$ を行ない, 終了後は, 経時的に サーモグラフィを行なった．用いたサーモグラ フ山富士通（株）医用赤外線映像装置インフラ アイである。

\section{結 果}

下腿の皮膚温が温浴後低下しはじめてから， 温浴前に戻るまでの時間は，上のような条件で は約 $20 \sim 30$ 分であったが，なかには麻痺側皮 膚温が急速に低下して $2 \sim 3$ 分後にはすでに温 浴前のものに戻るのもあった。また，温浴後の 皮膚温の経時的変動洼 1 のような 5 つのパタ ーンに分けることができた.

I 型：麻瘦側と健側との皮膚温の差が温浴前
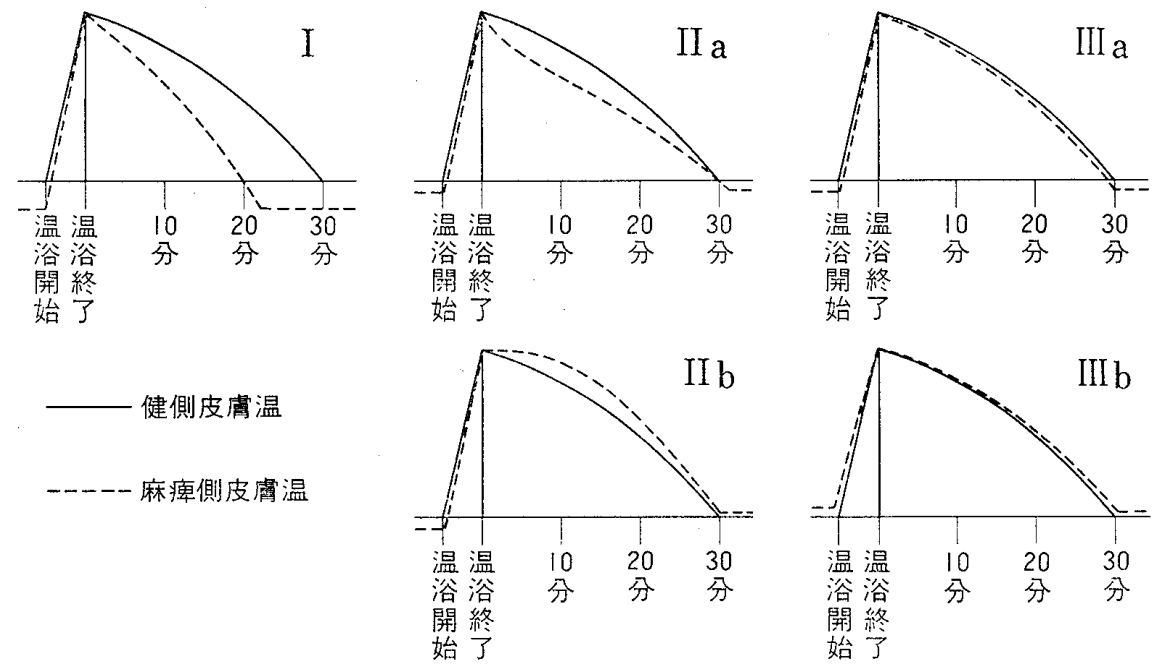

表 1 局所温浴 ( 6 分間, $40^{\circ} \mathrm{C} \sim 50^{\circ} \mathrm{C}$ ) 後の皮膚温低下パターン 
にも温浴後にも大きく，皮膚温の低下速度は健 側>麻㾝側であり，両側ともに温浴前の温度に 戻る型.このI型を示したものは脳血栓10名中 の 4 名, 脳塞栓 4 名中の 3 名, 脳出血14名中の 2 名, 脳動脈瘤術後 1 名の合計 10 名であった。

II $\mathrm{a}$ 型， $\Pi \mathrm{b}$ 型：温浴前には麻痺側と健側の 皮膚温の差は小さいが，温浴終了数分後にはそ の差が大きくなり，時間の経過とともに再びそ の差が小さくなる型で, II a 型で汹温浴終了後 の皮膚温の低下速度は健側<麻疩 側であり， II b 型では健側く麻痺側である。 II a 型を示し たものは脳出血14名の 1 名であり， II $\mathrm{b}$ 型を示 したものは脳血栓10名中の 3 名, 脳出血14名中 の1名であった。

III $\mathrm{a}$ 型， III $\mathrm{b}$ 型：麻瘦側と健側の皮膚温の差 が温浴前にも温浴後にも小さい型で, III a 型で は全経過を通じて皮膚温は，わずかに健側く麻 痺側であり，III 型ではわずかに健側>麻痺側 である、III a 型を示したものは脳血栓10名中の
2 名, 脳塞栓 4 名中の 1 名, 脳出血14名中の 7 名で合計10名であり， III b 型を示したものは脳 血栓10名中の 1 名, 脳出血14名中の 3 名で合計 4 名であった。

写真 1 は，44歳健康男性の両下腿サーモグラ ムであり, 温浴前, 温浴終了 2 分後, 10分後, 30分後のものであるが，左右差はほとんどなく， 温浴終了30分後に法左右ともに温浴前のものに 戻っている.

写真 2 は, 脳出血・右片麻痺の発作後約 1 年 2 か月の51歳女性の両下腿サーモグラムで, I 型を示した例である.温浴前には, 麻痺側の右 側は，健側の左側に比べて低温（右く左）であ り, 温浴終了 3 分後では右二左であり，15前後 では右く左となり，40分後に注全く温浴前に戻 っている.

写真 3 は, 脳出血・右片麻痺の発作後約 7 力 月の 37 歳男性の両下腿サーモグラムであり, II a 型を示した例である。温浴前には左右差は

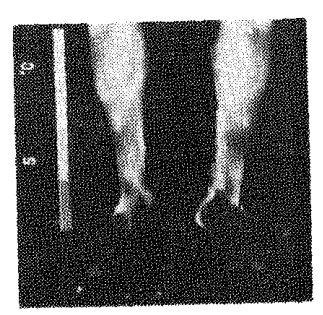

湿 浴 前

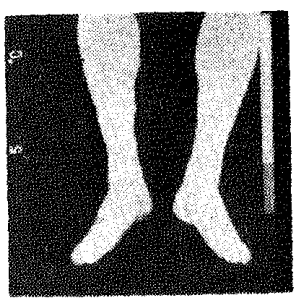

温浴終了徭 2 分経過

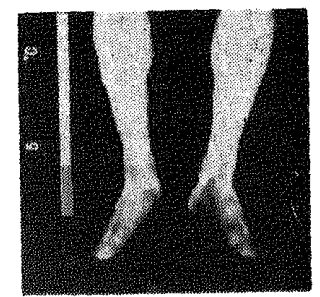

混浴終了後10分経過

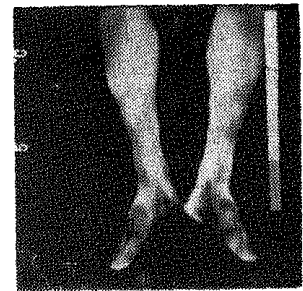

㼟浴終了後 30 分経遇

写真 1 健康者, 44歳男, 両下腿正面サーモグラム, 基準温度 $31^{\circ} \mathrm{C}$, 温度差 $5^{\circ} \mathrm{C}$

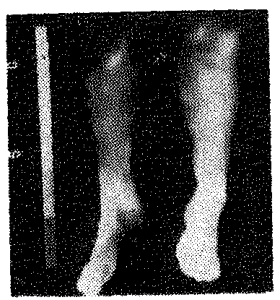

澏 浴 前

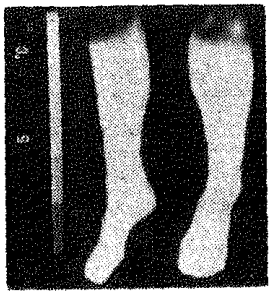

湿浴終了後 3 分経過

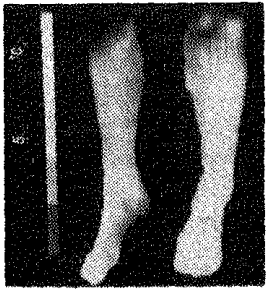

温浴終了婹15分経過

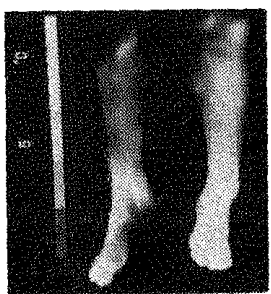

温浴終了後40分経遇

写真 2 脳出血・右片麻症，51歳女：両下腿サーモグラム，基準温度 $29^{\circ} \mathrm{C}$, 温度差 $5^{\circ} \mathrm{C}-\mathrm{I}$ 型一

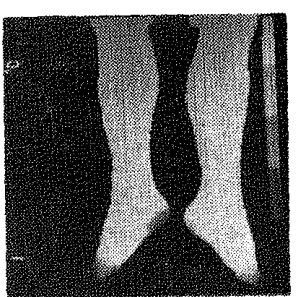

温 浴前

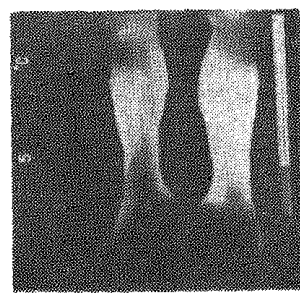

温浴終了後 6 分経過

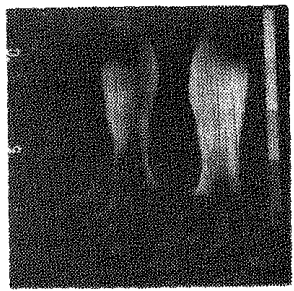

温浴終了後12分経過

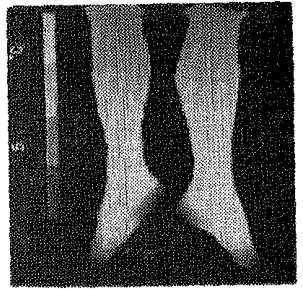

温浴終了後34分経過

写真 3 脳出血・右片麻渒, 37歳男, 両下腿正面サーモグラム、基準温度温浴前, $33^{\circ} \mathrm{C}$, 温度差 $5^{\circ} \mathrm{C}$. 温浴後 $39^{\circ} \mathrm{C}$, 温度差 $5^{\circ} \mathrm{C}, 1^{\circ} \mathrm{C}-\mathrm{II}$ a 型- 
(54)

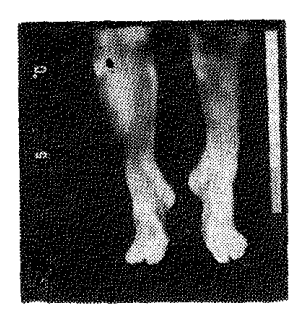

温 浴 前

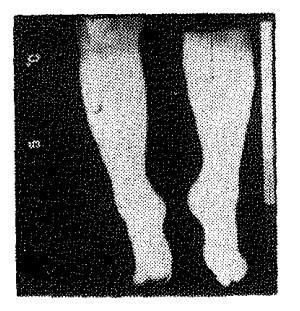

温浴終了後 3 分経過

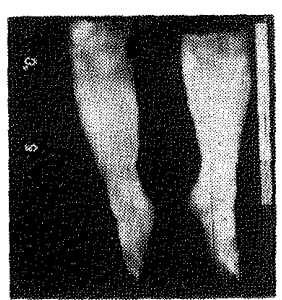

温浴終了後15分経過

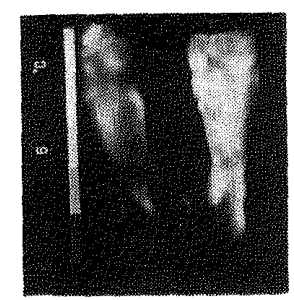

温浴終了後40分経過

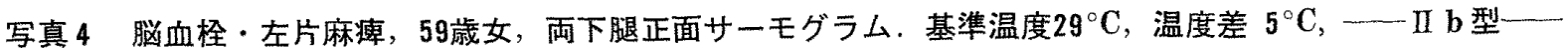

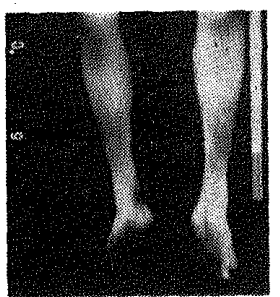

温. 浴 前

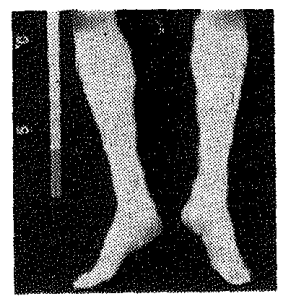

温浴終了後 2 分経過

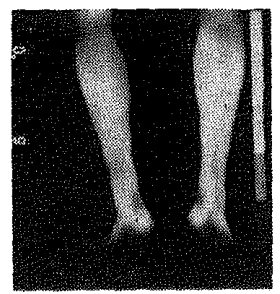

湿浴終了後 21 分経過

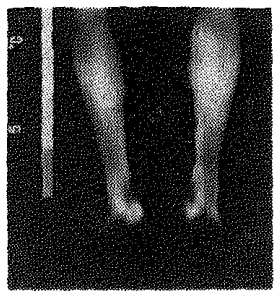

温浴終了後 35 分経過

写真 5 脳出血・右片麻㽻， 38 歳男，両下腿正面サーモグラム. 基準温度 $30^{\circ} \mathrm{C}$ ，温度差 $5^{\circ} \mathrm{C}-\mathrm{III}$ a 型—-

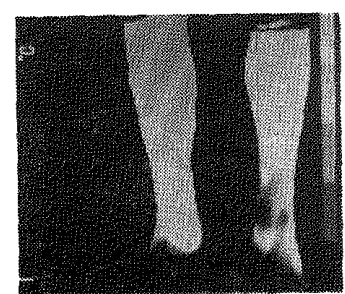

温浴 前

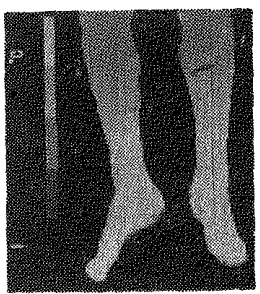

湿浴終了後 $\mathbf{5}$ 分経過

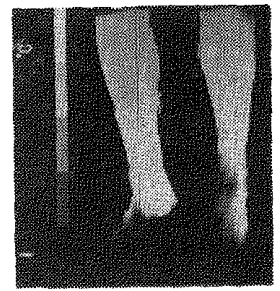

温浴終了後 26 分経過

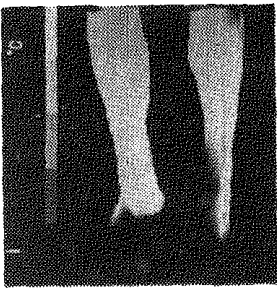

温浴終了後 39 分経過

写真 6 脳血栓・右片麻㾝, 63 歳男, 両下腿正面サーモグラム. 基準温度 $32^{\circ} \mathrm{C}$, 温度差 $1^{\circ} \mathrm{C}-$ - III b 型—

ほとんど認められないが，温浴終了 6 分後では 明らかに右側・麻痻側<左側・健側であり，12 分後では左右差が小さくなり，34分後では再び 左右差が認められない。

写真 4 は, 脳血栓・左片麻㽻の発作後約 2 年 9 力月の59歳女性の両下腿茾一モグラムであり, II b 型を示した例である. 温浴前には左側・麻 痺側<右側・健側であり, 温浴終了 3 分後では 左右差がなく，15分後では左側・麻痺側 >右側・ 健側となり，40分後にも同様である.

写真 5 注, 脳出血・右片麻痺の発作後約 7 力 月の 38 歳男性の雨下腿サーモグラムであり, III a 型を示した例である. 温浴前には, やや右 側・麻痺側<左側・健側であり, 温浴終了 3 分 後では左右差はなく, 21 分後では, やや右側・ 麻痺側<左側・健側となり, 35分後では温浴前 に戻っている。

写真 6 は, 脳血栓・右片麻痺の発作後約 1 年 2 力月の63歳男性の両下腿サーモグラムであり, III $_{b}$ 型を示した例である. 温浴前には, 足関節 上部に扔いて，左側・健側<右側・麻痺側であ
る. 温浴終了 5 分後では左右差がなく, 26 分後 でも同様であるが，39分後では温浴前に戻って いる。

\section{考 按}

表 1 のパターンを病型からだけみると，I 型 と II 型には脳硬塞，III型には脳出血が多いよう にもみえる。しかし病型の他に, 脳傷害の部位, その程度, 動脈の硬化度, 発作後の経過期間, 筋の萎縮程度, 年齢, 性, その他のことも考え に入れて、これらのパターンの発現機序を考察 しなくてはならないであろう。それにしても， 一応は血管運動神経に関連があるのではないか と思われる。

\section{結 語}

脳卒中後遺症患者における両下腿温浴後の皮 膚温の経時的変動様式を 5 つのパターンに分類 した．温浴終了後皮膚温が温浴前に戻るまでの 時間は約20〜30分であった。

(この研究の一部は昭和48年度厚生省医療研 究助成補助金によった・謝意を表す.) 